THURSDAY, MAY $24,1888$.

\section{THE POLYTECHNIC INSTITUTE.}

$\mathrm{E}$ ERY middle-aged inhabitant of the British Islands must recall more than one occasion when the mind of our country has been strongly stirred on the question of national defence. The adverse evidence of an expert, a rousing article in a newspaper, has often awakened general anxiety of more or less continuance, and followed by more or less adequate results. But it is far more difficult to awaken any widespread concern on behalf of those great abiding national interests which it is our charge and heritage to defend. And yet there are signs of no uncertainty which must to all thoughtful and instructed minds, from many directions, suggest the question whether that industrial leadership which has hitherto made our small and crowded country the world's workshop, and almost the world's mart, is not slipping from us. This is a question not of more or less wealth or luxury, but of very livelihood to the masses of the people under the special conditions of our national existence. If work ceases to come to a workshop, there is nothing for it but prompt dispersal of the workmen. All authorities seem agreed that the population of five or six millions inhabiting England and Wales in the time of Queen Elizabeth represents pretty nearly what their areas can sustain as agricultural, selfsupporting countries. But the population of England and Wales alone was shown by the census of 188 I to have reached nearly twenty-six millions. So that seven years ago there was in the southern half of Great Britain an excess of twenty millions above what the country could reasonably support, except as a community of artificers and traders, and general carriers, by import and export, of the world's merchandise. It needs only a glance into past history to see that this, while an enviable position for a nation while prosperity lasts, is practical extinction when the cbannels of commerce are turned, or lost advantages have transferred production to new centres. Macaulay's fancy picture of the New Zealander sketching the ruins of St. Paul's from the broken arches of London Bridge seems of very little concern to the present citizen, whose ears are deafened with the ceaseless roar and traffic of the streets. And yet precisely that doom of silence and decay has befallen many a proud mother-city of which now "even the ruins have perished." It would far exceed present limits to show in detail how many articles of our own immemorial production we ourselves now largely import, because the foreign workman produces them better, or produces them at less cost. The evidence will be fresh in the recollection of the readers of this journal. Neither can they fail to recall with what persistence we have pointed out the remedy. There is but one real remedy: the better training of the workman; and-if we may be allowed to say it-of his employer too. Everyone who, without prejudice, has opportunity to watch a fair specimen of the British workman at his work must admit that the raw material is as good as ever it was; that in the quantity and quality of the work he can turn out in a given time, few of any nationality can equal, and none VoI. XXXviII.-No. 969. surpass him. But in the training he receives, and in the opportunities of his receiving it, there is much left to be desired. And, meantime, there is not only the grave fear, but, in many branches of industry, the accom. plished fact, that other nations may and do outstrip us in the race.

Perhaps there is some belated merit in seeing that now; but all honour to those who, with heart and means to labour towards the better training of our artisans, devoted themselves to the endeavour when the need for it was less comparatively obvious. Honour especially to one man, Mr. Quintin Hogg, who, close upon a quarter of a century ago, at an age when most young men are concentrating their best energies on cricket, or football, or lawn tennis (all good things in their way), made it his life's task to raise the skilled workman of London, and furnish him more fully for his labour, for his own sake and for ours. Probably most of our readers know how that small enterprise has become a great one indeed, with the old Polytechnic for its present home and centre, and with a fuller variety of classes and branches, and with a greater comprehensiveness of scheme, than we can now attempt to describe. But all has hitherto rested on the shoulders, and been sustained by the purse, of Mr. Hogg himself, who, during the past six years, has spent, speaking broadly, some $£ 100, \infty 00$ in establishing and sustaining these admirable schools. But the time has now come when so great a burden, for the work's sake as well as for his own, should no longer depend upon the means and life of a single man; and there is now an opportunity of securing for the Institute something like an adequate endowment. The Charity Commissioners have offered to endow it with $£ 2500$ per annum on condition that the public find $£ 35,000$ as a supplementary fund. $£$ i 8,000 have already been promised by the personal friends of the founder; but $£ 17,000$ still remain to be raised-a large sum no doubt, but a small one compared to our still unrivalled resources, and the national value of the Institute, not only for its own immediate results, but as a model for similar efforts in all the great centres of our industry. Those who believe in science-that is, in faithfully accurate and exact knowledge-as the only sure basis for any national prosperity that is to bear the stress of the fierce competition of our times, are earnestly invited to make themselves acquainted with the work of the Institute, and to contribute to its funds. Eighty-one thousand members and students have joined since it was moved to the Polytechnic, 309 Regent Street, in 1882. All donations or subscriptions will be thankfully received there, or by $\mathrm{Mr}$. Quintin Hogg, 3 Cavendish Square, W.

\section{THE GEOGRAPHICAL DISTRIBUTION OF} THE FAMILY CHARADRIID AE.

The Geographical Distribution of the Family Charadriidce; or the Plovers, Sandpipers, Snipes, and their Allies. By Henry Seebohm. (London: H. Sotheran and Co., r888.)

THIS is a handsome volume of more than 500 pages, and it is illustrated by twenty-one coloured plates, drawn in Mr. Keuleman's best style. Mr. Seebohm has eschewed giving much information as to the habits of 